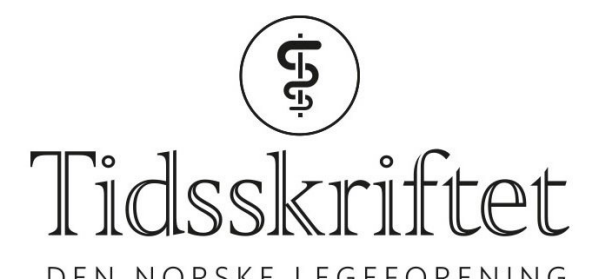

DEN NORSKE LEGEFORENING

\title{
Er eldre HUNT-deltagere friskere enn
} før?

ORIGINALARTIKKEL

\section{RAGNHILD HOLMBERG AUNSMO}

E-post: ragnhild.holmberg.aunsmo@innherred-samkommune.no Innherred samkommune

Levanger

Hun har bidratt i utviklingen av idé, utforming, analyse av data, tolkning, litteratursøk og utarbeiding av selve manuset og har godkjent innsendte manusversjon.

Ragnhild Holmberg Aunsmo (f. 1967) er spesialist i samfunnsmedisin og kommuneoverlege i

Innherred samkommune (Levanger og Verdal).

Forfatter har fylt ut ICMJE-skjemaet og oppgir ingen interessekonflikter.

\section{JOSTEIN HOLMEN}

HUNT forskningssenter

Institutt for samfunnsmedisin

Norges teknisk-naturvitenskapelige universitet

Levanger

Han har bidratt i utviklingen av idé, utforming, analyse av data, tolkning, litteratursøk og utarbeiding av selve manuset og har godkjent innsendte manusversjon.

Jostein Holmen (f. 1947) er professor i anvendt samfunnsmedisin og tidligere leder for Helseundersøkelsen i Nord-Trøndelag (HUNT) og HUNT forskningssenter, Norges teknisk-

naturvitenskapelige universitet.

Forfatter har fylt ut ICMJE-skjemaet og oppgir ingen interessekonflikter.

\section{BAKGRUNN}

Siden det blir mange flere eldre fremover, er kunnskap om deres helseutvikling viktig i samfunnsplanleggingen. Målet med denne studien var å undersøke tendenser i helseutviklingen hos eldre over 70 år i Nord-Trøndelag.

\section{MATERIALE OG METODE}

I Helseundersøkelsen i Nord-Trøndelag (HUNT) har vi samlet helsedata i tre runder: HUNT1 (1984-86), HUNT2 (1995-97) og HUNT3 (2006-08). Ved hjelp av tverrsnittsanalyser har vi studert endringer hos dem som er 70 år og eldre når det gjelder selvrapportert helse, funksjonsnivå og bruken av helsetjenester. Materialet inkluderer 12391 personer ( $85 \%$ deltagelse) i HUNT1, 11069 (69,3\% deltakelse) i HUNT2 og 8194 i HUNT 3 (54,7\% deltagelse). 
Subjektiv helse og fungering i dagliglivet (ADL-funksjoner) ble vurdert til å være bedre ved HUNT3 enn ved HUNT2. Egenrapportert fysisk aktivitet $ø$ kte fra HUNT1 til HUNT3. Bruken av hjemmehjelp minsket fra HUNT2 til HUNT3, mens bruken av sykehjem og hjemmesykepleie var uendret. Bruken av allmennlege $ø$ kte for hver periode, mens bruk av poliklinikk $\emptyset \mathrm{kte}$ kraftig fra HUNT1 til HUNT2.

\section{FORTOLKNING}

Det ser ut til at eldre nordtrøndere synes de har bedre helse, at de er blitt mer selvhjulpne og mer fysisk aktive i perioden fra 1984 til 2008, men funnene må tolkes med noe forsiktighet på grunn av den fallende deltagelsen i undersøkelsen fra HUNT1 til HUNT3.

Befolkningsprognosene tilsier at antall eldre vil øke kraftig i årene fremover, dels på grunn av de store etterkrigskullene og dels fordi levealderen stiger. Dødeligheten av mange sykdommer synker fordi det finnes bedre måter å behandle dem på enn tidligere, dermed vil flere mennesker leve med sykdom (1). Samtidig kan sunnere livsstil og bedre behandlingsmuligheter føre til endringer i

\section{aldringsprosessen (2), men det er ulike teorier om hvordan dette vil slå ut.}

«Kompresjonshypotesen» (3) tilsier at vi får flere år med god helse og funksjon, fordi sykdommene vil debutere senere og dermed bli komprimert til de siste leveårene. Ifølge «ekspansjonshypotesen» (4) må vi leve lenger med sykdom og dårlig helse enn tidligere, fordi flere overlever og blir gamle med sykdommer som man før døde tidlig av. Tilhengerne av «ekvilibriumshypotesen» (5) antar at befolkningen samlet sett vil ha like stor sykdomsbyrde - det vil være en lavere andel med alvorlige sykdommer og funksjonsnedsettelse samtidig som det vil være en høyere andel med moderate eller mindre alvorlige lidelser og funksjonshemninger (6).

Funnene spriker når det gjelder å anslå hvilken hypotese som er mest sannsynlig (7). Dårlig selvrapportert helse ser ut til å henge mer sammen med alvorlig funksjonssvikt enn med antall diagnoser og lett grad av funksjonssvikt (8). Dette er i tråd med Peter F. Hjorts definisjon av helse som overskudd til å mestre hverdagens krav (9).

For å kunne planlegge helse- og omsorgstjenestene er det viktig å få kunnskap om hva man kan forvente av behov både for medisinsk oppfølging og for praktisk bistand. Flere studier tyder på at eldre mennesker har bedre helse og er i bedre fysisk form enn før.

Svenske (10-12) og amerikanske $(13,14)$ unders $ø$ kelser tyder på at andelen med diagnostisert kronisk sykdom øker, men at færre har en subjektiv opplevelse av å ha dårlig helse. I en studie fra England beskrev man mindre funksjonssvikt (15), men ingen endring $\mathrm{i}$ selvrapportert opplevelse av helse. Fra Spania (16) er det beskrevet at alvorlig funksjonssvikt inntraff senere, men at det for kvinner var betydelig reduksjon i selvhjulpenhet.

Også hos dem over go år ventes det utvikling av en større hjelptrengende befolkningsgruppe (17) i Spania, mens i en dansk studie ble det ikke vist at de aller eldste fikk større behov for hjelp i siste del av livet (18). I denne studien ble alle som var født i Danmark i 1905 og bodde i landet i 1998 inkludert, til sammen 2262 personer. Denne gruppen er sammenlignet med kohorten som var født ti år tidligere. Resultatene viste at 1905-årgangen var sterkere og friskere (19).

I Norge har vi kommet kortere innen forskning på eldres helse enn i de andre skandinaviske 
land. Målet med denne studien var å analysere hvordan helsetilstanden hos eldre endret seg i perioden fra 1984-86 til perioden 2006-08. Vi har brukt data fra Helseunders $ø$ kelsen i Nord-Trøndelag (HUNT). Helseundersøkelsen i Nord-Trøndelag er et samarbeidsprosjekt mellom HUNT forskningssenter (Det medisinske fakultet, Norges teknisknaturvitenskapelige universitet), Nord Trøndelag fylkeskommune, Helse Midt-Norge og Folkehelseinstituttet.

\section{Materiale og metode}

HUNT er en stor befolkningsundersøkelse som er gjennomført i tre runder - HUNT1 (1984-86), HUNT2 (1995-97) og HUNT3 (2006-o8). Alle de tre undersøkelsene er gjennomført etter stort sett samme mønster.

Alle som var bosatt i Nord-Trøndelag ble invitert, ved HUNT1 var nedre aldersgrense 20 år, ved HUNT2 og HUNT3 var den 13 år. Det var ingen øvre aldersgrense.

Ved HUNT1 svarte 12391 personer som var 70 år eller eldre (85\%) på spørreskjema 1, ved HUNT2 11 o69 personer (69,3\%) og ved HUNT3 8194 personer (54,7\%) (tab 1). Alle fikk en personlig invitasjon i posten sammen med et spørreskjema (skjema 1) med blant annet spørsmål om egenvurdert helse, livsstil, sykdommer og bruk av helsetjenester. Utfylt skjema ble levert ved fremmøte til den kliniske undersøkelsen, der det blant annet ble målt høyde, vekt og blodtrykk og tatt blodprøver og urinprøver. De fikk her utdelt et nytt skjema (skjema 2) med flere spørsmål om livsstil og ulike sykdommer samt funksjoner i dagliglivet (ADL). Det skulle de fylle ut og sende inn per post. Kvinner og menn fikk ikke samme skjema 2, og ved HUNT2 og HUNT3 var det egne skjemaer 2 til aldersgruppen 70 år og eldre. Metodene er detaljert beskrevet tidligere (20-22).

\section{Tabell 1}

Deltakelse ved HUNT1, HUNT2 og HUNT3 for personer som er 7o år og eldre. Antall som besvarte spørreskjema 1 (tilsendt før undersøkelsen og innlevert ved fremmøte) og antall som besvarte spørreskjema 2 (innsendt per post etter undersøkelsen). I parentes angis antall besvarte i prosent av antall inviterte

\begin{tabular}{|c|c|c|c|c|c|c|c|c|c|c|c|c|}
\hline & \multicolumn{4}{|c|}{ Menn } & \multicolumn{4}{|c|}{ Kvinner } & \multicolumn{4}{|c|}{ Totalt } \\
\hline & \multicolumn{2}{|c|}{ Skjema 1} & \multicolumn{2}{|c|}{ Skjema 2} & \multicolumn{2}{|c|}{ Skjema 1} & \multicolumn{2}{|c|}{ Skjema 2} & \multicolumn{2}{|c|}{ Skjema 1} & \multicolumn{2}{|c|}{ Skjema 2} \\
\hline \begin{tabular}{|l|} 
Alder \\
(år)
\end{tabular} & \multicolumn{2}{|c|}{ Antall (\%) } & \multicolumn{2}{|c|}{ Antall (\%) } & \multicolumn{2}{|c|}{ Antall (\%) } & \multicolumn{2}{|c|}{ Antall (\%) } & \multicolumn{2}{|c|}{ Antall (\%) } & \multicolumn{2}{|c|}{ Antall (\% } \\
\hline $\begin{array}{l}\text { HUNT1 } \\
70-79\end{array}$ & $\begin{array}{r}4 \\
006 \\
\end{array}$ & $(89,5)$ & $\begin{array}{r}3 \\
610 \\
\end{array}$ & $(80,7)$ & $\begin{array}{r}4 \\
841 \\
\end{array}$ & $(90,3)$ & $\begin{array}{r}4 \\
277 \\
\end{array}$ & $(79,8)$ & $\begin{array}{r}8 \\
847 \\
\end{array}$ & $(89,9)$ & $\begin{array}{r}7 \\
887 \\
\end{array}$ & $(80,2)$ \\
\hline $80-89$ & $\begin{array}{r}1 \\
327 \\
\end{array}$ & $(77,7)$ & $\begin{array}{r}1 \\
086 \\
\end{array}$ & $(63,6)$ & $\begin{array}{r}1 \\
860 \\
\end{array}$ & $(75,8)$ & $\begin{array}{r}1 \\
421 \\
\end{array}$ & $(57,9)$ & $\begin{array}{r}3 \\
187 \\
\end{array}$ & $(76,6)$ & $\begin{array}{r}2 \\
507 \\
\end{array}$ & $(60,2)$ \\
\hline $90+$ & 128 & $(62,4)$ & 78 & (38) & 229 & $(59,9)$ & 132 & $(34,6)$ & 357 & $(60,8)$ & 210 & $(35,8)$ \\
\hline Totalt & $\begin{array}{r}5 \\
461 \\
\end{array}$ & $(85,5)$ & $\begin{array}{r}4 \\
774 \\
\end{array}$ & $(74,7)$ & $\begin{array}{r}6 \\
930 \\
\end{array}$ & $(84,5)$ & $\begin{array}{r}5 \\
830 \\
\end{array}$ & $(71,1)$ & $\begin{array}{r}12 \\
391 \\
\end{array}$ & (85) & $\begin{array}{r}10 \\
604 \\
\end{array}$ & $(72,7)$ \\
\hline \multicolumn{13}{|l|}{ HUNT2 } \\
\hline $70-79$ & $\begin{array}{r}3 \\
646 \\
\end{array}$ & $(77,2)$ & $\begin{array}{r}3 \\
332 \\
\end{array}$ & $(70,5)$ & $\begin{array}{r}4 \\
351\end{array}$ & $(76,7)$ & $\begin{array}{r}3 \\
989 \\
\end{array}$ & $(70,3)$ & $\begin{array}{r}7 \\
997 \\
\end{array}$ & $(76,9)$ & $\begin{array}{r}7 \\
321\end{array}$ & $(70,4)$ \\
\hline $80-89$ & $\begin{array}{r}1 \\
110\end{array}$ & $(60,9)$ & 943 & $(51,8)$ & $\begin{array}{r}1 \\
707\end{array}$ & $(56,3)$ & $\begin{array}{r}1 \\
361\end{array}$ & $(44,9)$ & $\begin{array}{r}2 \\
817\end{array}$ & $(58,1)$ & $\begin{array}{r}2 \\
304 \\
\end{array}$ & $(47,5)$ \\
\hline $90+$ & 90 & $(39,1)$ & 52 & $(22,6)$ & 165 & $(32,9)$ & 87 & $(17,4)$ & 255 & $(34,9)$ & 139 & (19) \\
\hline Totalt & $\begin{array}{r}4 \\
846 \\
\end{array}$ & $(71,5)$ & $\begin{array}{r}4 \\
327 \\
\end{array}$ & $(63,8)$ & $\begin{array}{r}6 \\
223 \\
\end{array}$ & $(67,6)$ & $\begin{array}{r}5 \\
437 \\
\end{array}$ & $(59,1)$ & $\begin{array}{r}11 \\
069 \\
\end{array}$ & $(69,3)$ & $\begin{array}{r}9 \\
764 \\
\end{array}$ & $(61,1)$ \\
\hline \multicolumn{13}{|l|}{ HUNT3 } \\
\hline $70-79$ & $\begin{array}{r}2 \\
667 \\
\end{array}$ & $(66,5)$ & $\begin{array}{r}2 \\
365 \\
\end{array}$ & (59) & $\begin{array}{r}3 \\
087 \\
\end{array}$ & $(67,4)$ & $\begin{array}{r}2 \\
785 \\
\end{array}$ & $(60,8)$ & $\begin{array}{r}5 \\
754 \\
\end{array}$ & (67) & $\begin{array}{r}5 \\
150 \\
\end{array}$ & $(59,9)$ \\
\hline $80-89$ & 953 & $(45,3)$ & 802 & $(38,2)$ & $\begin{array}{r}1 \\
335 \\
\end{array}$ & $(39,3)$ & $\begin{array}{r}1 \\
120 \\
\end{array}$ & (33) & $\begin{array}{r}2 \\
288 \\
\end{array}$ & $(41,6)$ & $\begin{array}{r}1 \\
922 \\
\end{array}$ & (35) \\
\hline $90+$ & 48 & $(21,1)$ & 34 & $(14,9)$ & 104 & $(15,7)$ & 82 & $(12,4)$ & 152 & $(17,1)$ & 116 & (13) \\
\hline Totalt & $\begin{array}{r}3 \\
668 \\
\end{array}$ & $(57,8)$ & $\begin{array}{r}3 \\
201\end{array}$ & $(50,5)$ & $\begin{array}{r}4 \\
526\end{array}$ & $(52,4)$ & $\begin{array}{r}3 \\
987\end{array}$ & $(46,2)$ & $\begin{array}{r}8 \\
194\end{array}$ & $(54,7)$ & $\begin{array}{r}7 \\
188 \\
\end{array}$ & (48) \\
\hline
\end{tabular}


For denne studien valgte vi ut spørsmål som var stilt på identisk måte eller var sammenlignbare. Subjektiv helse ble målt med spørsmålet «Hvordan er helsa di nå?», med fire svaralternativer: «dårlig», «ikke helt god», «god» og «svært god». I fremstillingen har vi slått sammen de som svarte god og svært god og sett på hvilken andel disse utgjør. I HUNT2 og HUNT3 ble deltagerne spurt om de mestret ulike daglige aktiviteter (ADL): «Klarer du selv, uten hjelp av andre, i det daglige å gå innendørs i samme etasje, gå på toalettet osv.?» (23). Svaralternativene var ja/nei, men i HUNT2 var det også et tredje alternativ: «med noe hjelp». Vi studerte dem som svarte «ja», da vi antok at de som valgte «med noe hjelp» ellers hadde svart «nei».

Ved HUNT1 og HUNT3 ble det stilt identiske spørsmål om fysisk aktivitet. For hyppighet var svaralternativene «aldri» (o poeng), «sjeldnere enn en gang i uken» (1 poeng), «en gang $\mathrm{i}$ uken» (2 poeng), «2-3 ganger i uken» (3 poeng) og «omtrent hver dag» (4 poeng). For intensitet var svaralternativene «tar det rolig uten å bli andpusten» (1 poeng), «tar det så hardt at jeg blir andpusten og svett» (2 poeng), «tar meg nesten helt ut» (3 poeng). For varighet var svaralternativene $<5$ min (1 poeng), $15-29$ min ( 2 poeng), 30 min- 1 time (3 poeng), > 1 time (4 poeng). For å lette sammenligningen beregnet vi en indeks $(24,25)-$ produktet av svarene ga en indeks for fysisk aktivitet med bredde $0-48$ poeng.

I HUNT2 og HUNT3 ble det spurt om bruken av hjemmehjelp, hjemmesykepleie og om vedkommende hadde hatt noe institusjonsopphold siste året. I alle de tre HUNTundersøkelsene ble det spurt om deltagerne hadde vært hos allmennlege eller lege ved sykehus. Deltagerne svarte også på om de hadde ulike sykdommer. I HUNT1 svarte de ja/nei på om de hadde hatt sukkersyke (diabetes), hjerteinfarkt, angina pectoris (hjertekrampe) eller hjerneslag/hjerneblødning. De fikk også spørsmål om de hadde langvarig sykdom, plage eller lyte som hemmet dem i dagliglivet, herunder psykisk sykdom. I HUNT2 fikk de i tillegg spørsmål om astma. Vi slo sammen variablene hjerteinfarkt og angina pectoris til koronarsykdom, og valgte å holde oss til disse sykdommene fordi de var med i alle de tre helseundersøkelsene.

\section{STATISTIKK}

Vi har stratifisert materialet i femårige aldersgrupper og kjønn. Nominale data er signifikanstestet med enkel t-test, mens vi for kategoriske data har brukt andeler og beregnet konfidensintervall. En p-verdi < 0,05 ble ansett som statistisk signifikant.

\section{ETIKK}

HUNT er basert på informert samtykke, og både HUNT1, HUNT2 og HUNT3 er godkjent av Datatilsynet. HUNT2 og HUNT3 er godkjent av regional komité for medisinsk og helsefaglig forskningsetikk (REK) (da HUNT1 ble gjennomført, var de regionale etiske komiteene ennå ikke etablert).

Denne studien er godkjent av regional komité for medisinsk og helsefaglig forskningsetikk.

\section{Resultater}

\section{SUBJEKTIV HELSE}

Den subjektive helsen ble gradvis bedre i perioden fra 1984-86 til perioden 2006-07. I HUNT1 rapporterte 43,8\% av kvinnene at de hadde god/svært god helse, i HUNT2 47,1\% og i HUNT3 $33,6 \%$. Tilsvarende tall for menn var $52,6 \%, 54,4 \%$ og $60,2 \%$. Det var samme tendens i nesten alle aldersgrupper (fig 1 ). 


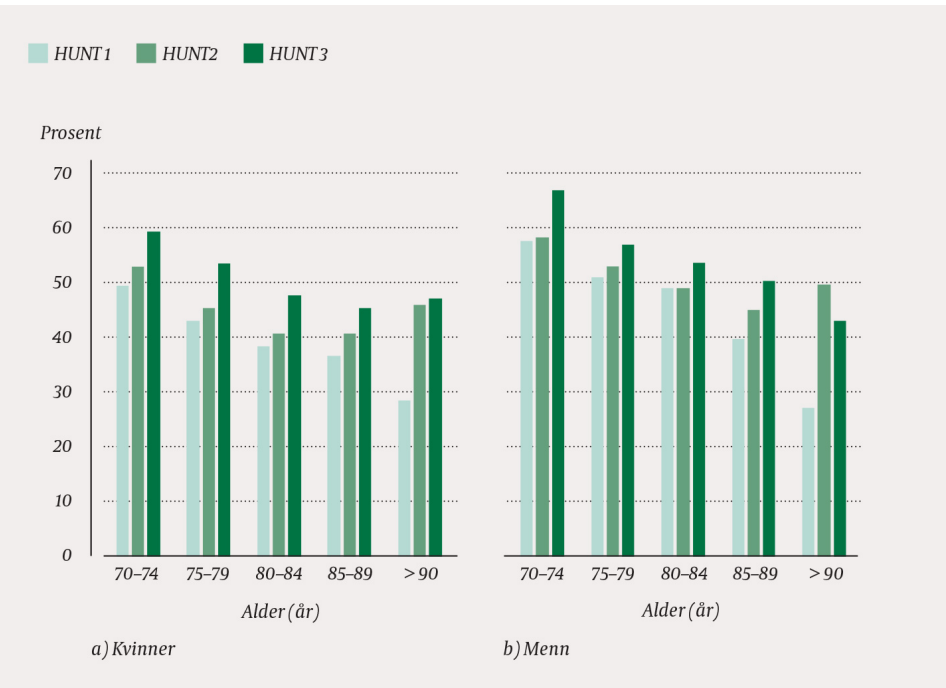

Figur 1 Subjektiv helseoppfatning hos deltagere som var 70 år og eldre ved HUNT1, HUNT2 og HUNT3 hos a) kvinner og b) menn. Andelen som svarte «god» eller «svcert god» på spørsmålet «Hvordan er helsa di nå?». Aldersfordelt

\section{AKTIVITETER I DAGLIGLIVET (ADL-FUNKSJONER)}

Både ved HUNT2 og HUNT3 ble det spurt om i alt 16 ulike ADL-funksjoner. For nesten alle funksjonene var det bedring fra HUNT2 til HUNT3, og dette gjaldt begge kjønn (fig 2). Særlig innen de ni personlige ADL-funksjonene som ble vurdert var det stor grad av mestring.

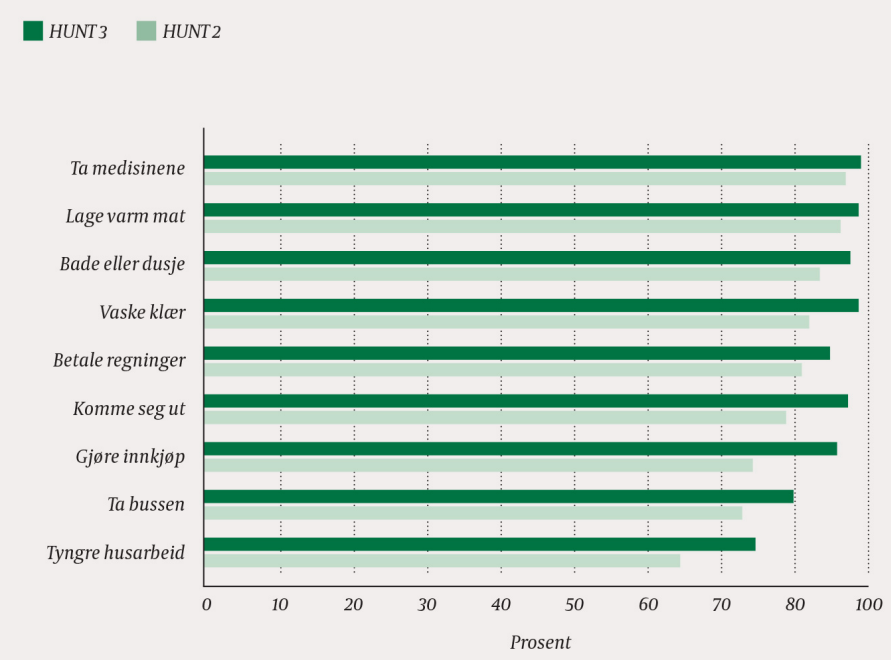

a) Kvinner

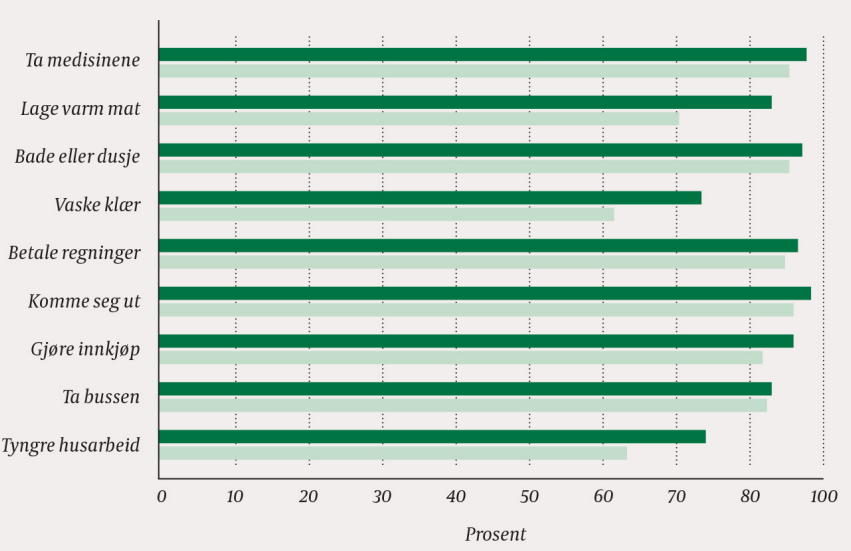

b) Menn

Figur 2 ADL-funksjoner ved HUNT2 og HUNT3. Andel av a) kvinner og b) menn 70 år og eldre som anga at de greide ulike daglige aktiviteter uten hjelp 
Innenfor de syv instrumentelle ADL-funksjonene (iADL) var det noe mer svikt. I HUNT2 svarte $71 \%$ av mennene og $72 \%$ av kvinnene at de greide tyngre husarbeid, mot $83 \%$ av begge kjønn i HUNT3. Å lage varm mat klarte bare 79\% av mennene i HUNT2, mens i HUNT3 var det 93\% som svarte at de greide det. Tilsvarende tall for kvinner var henholdsvis $96 \%$ og $98 \%$ Alle disse endringene var statistisk signifikante.

\section{FYSISK AKTIVITET}

Både menn og kvinner rapporterte mer fysisk aktivitet i HUNT3 enn i HUNT1. Dette gjaldt alle aldersgrupper. Indeksen for fysisk aktivitet økte fra 4,o9 til 8,38 for kvinner, for menn $\emptyset$ kte den fra 7,67 til 10,82 (fig 3).

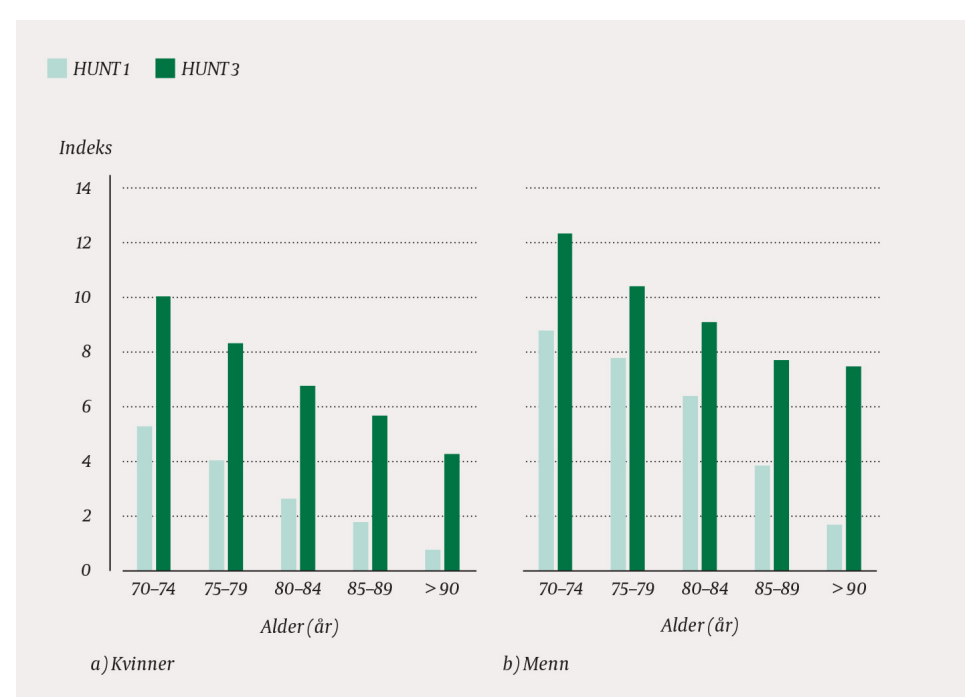

Figur $_{3}$ Egenrapportert fysisk aktivitet hos deltagere som var 70 år og eldre ved HUNT1 og HUNT3 hos a) kvinner og b) menn. Aldersfordelt. Indeks: produktet av hyppighet og intensitet og varighet

\section{BRUK AV KOMMUNALE TJENESTER}

Signifikant færre fikk hjemmehjelp i HUNT3 enn i HUNT2. En høyere andel kvinner enn menn hadde hjemmehjelp, men nedgangen gjaldt begge kjønn og alle aldersgrupper (tab 2). Bruken av hjemmesykepleie var omtrent uendret fra HUNT2 til HUNT3 og høyere for kvinner enn for menn.

\section{Tabell 2}

Kommunale tjenester. Antall (n) og andel (\%) som oppgir å ha hatt hjemmehjelp, hjemmesykepleie og institusjonsopphold i løpet av de siste $12 \mathrm{~m}$. *Endringen er signifikant

\begin{tabular}{|c|c|c|c|c|c|c|c|c|c|c|}
\hline \multirow[b]{3}{*}{ Alder (år) } & \multicolumn{4}{|c|}{ Kvinner } & \multicolumn{6}{|c|}{ Menn } \\
\hline & \multicolumn{2}{|c|}{ HUNT2 } & \multicolumn{2}{|c|}{ HUNT3 } & \multirow[t]{2}{*}{$*$} & \multicolumn{2}{|c|}{ HUNT2 } & \multicolumn{2}{|c|}{ HUNT3 } & \multirow[t]{2}{*}{ * } \\
\hline & Antall & $(\%)$ & Antall & $(\%)$ & & Antall & $(\%)$ & Antall & $(\%)$ & \\
\hline \multicolumn{11}{|c|}{ Hjemmehjelp } \\
\hline $70-74$ & 147 & $(9,5)$ & 49 & $(4)$ & * & 88 & $(6)$ & 30 & $(2,74)$ & * \\
\hline $75-79$ & 228 & $(17,9)$ & 89 & $(8,7)$ & * & 126 & $(12,1)$ & 38 & $(4,71)$ & * \\
\hline $80-84$ & 265 & $(35,6)$ & 143 & $(21,8)$ & * & 126 & $(24,2)$ & 73 & $(14,09)$ & * \\
\hline $85-89$ & 160 & $(54,8)$ & 108 & $(40,6)$ & * & 89 & $(42,8)$ & 47 & $(29,56)$ & \\
\hline $90+$ & 51 & (68) & 46 & $(59,7)$ & & 25 & $(51)$ & 13 & $(41,94)$ & \\
\hline $70+$ & 851 & $(21,7)$ & 435 & $(13,4)$ & * & 454 & $(13,8)$ & 201 & $(7,71)$ & * \\
\hline \multicolumn{11}{|c|}{ Hjemmesykepleie } \\
\hline $70-74$ & 49 & (3) & 33 & $(2,9)$ & & 25 & $(1,6)$ & 21 & $(2,03)$ & \\
\hline $75-79$ & 83 & $(6,3)$ & 48 & $(5,1)$ & & 61 & $(5,6)$ & 25 & $(3,29)$ & \\
\hline $80-84$ & 95 & $(12,5)$ & 85 & $(13,6)$ & & 36 & $(6,7)$ & 38 & $(7,84)$ & \\
\hline $85-89$ & 60 & (21) & 56 & $(22)$ & & 31 & $(15,2)$ & 23 & $(14,38)$ & \\
\hline
\end{tabular}




\begin{tabular}{|c|c|c|c|c|c|c|c|c|c|c|}
\hline \multirow[b]{3}{*}{ Alder (år) } & \multicolumn{4}{|c|}{ Kvinner } & \multicolumn{6}{|c|}{ Menn } \\
\hline & \multicolumn{2}{|c|}{ HUNT2 } & \multicolumn{2}{|c|}{ HUNT3 $_{3}$} & \multirow[t]{2}{*}{$*$} & \multicolumn{2}{|c|}{ HUNT2 } & \multicolumn{2}{|c|}{ HUNT3 $_{3}$} & * \\
\hline & Antall & $(\%)$ & Antall & $(\%)$ & & Antall & (\%) & Antall & $(\%)$ & \\
\hline $90+$ & 19 & $(27,9)$ & 24 & $(32,9)$ & & 13 & $(28,9)$ & 8 & (25) & \\
\hline $70+$ & 306 & $(7,5)$ & 246 & $(8,1)$ & & 166 & $(4,9)$ & 115 & $(4,66)$ & \\
\hline \multicolumn{10}{|c|}{ Institusjonsopphold } & \\
\hline $70-74$ & 32 & (2) & 21 & $(1,8)$ & & 43 & $(2,9)$ & 44 & $(4,3)$ & \\
\hline $75-79$ & 65 & $(5,2)$ & 49 & $(5,1)$ & & 42 & $(3,9)$ & 53 & (7) & \\
\hline $80-84$ & 75 & $(10,3)$ & 43 & $(6,8)$ & & 45 & $(8,4)$ & 31 & $(6,4)$ & \\
\hline $85-89$ & 41 & $(14,7)$ & 18 & $(6,9)$ & & 22 & $(10,6)$ & 14 & $(8,9)$ & \\
\hline $90+$ & 11 & $(15,5)$ & 8 & $(11)$ & & 13 & $(27,1)$ & 5 & $(16,7)$ & \\
\hline $70+$ & 224 & $(5,7)$ & 139 & $(4,5)$ & & 165 & $(4,9)$ & 147 & (6) & \\
\hline
\end{tabular}

Ved HUNT2 oppga 5,7\% av kvinnene å ha hatt kommunalt institusjonsopphold siste år, mot $4,5 \%$ ved $\mathrm{HUNT}_{3}$, og nedgangen gjaldt de eldste. For menn var det en økning fra 4,9\% ved HUNT2 til 6\% ved HUNT3.

\section{BRUK AV LEGER OG SYKEHUS}

Det var gradvis og signifikant $ø$ kning i bruken av allmennlege fra HUNT1 til HUNT3 for begge kjønn og i alle aldersgrupper (69,2\%, 84,0\%, 90,5\% for kvinner ved HUNT1, HUNT2 og HUNT3 og 64,5\%, 83,0\%, 91,o for menn) ( $\left.\operatorname{tab}_{3}\right)$.

\section{Tabell 3}

Selvrapportert bruk av allmennpraktiserende lege og lege ved sykehusenes poliklinikker ved HUNT1, HUNT2 og HUNT3. Deltagere i aldersgruppen 70 år og eldre, aldersfordelt. Andel (\%) som anga at de hadde brukt tjenestene de siste 12 månedene

\begin{tabular}{|lcccccc|}
\hline & \multicolumn{3}{c}{ Kvinner } & \multicolumn{3}{c|}{ Menn } \\
\hline Alder (år) & HUNT1 HUNT2 HUNT3 HUNT1 HUNT2 HUNT3 \\
\hline $\begin{array}{l}\text { Allmennpraktiker } \\
70-74\end{array}$ & 68,5 & 84,0 & 89,9 & 62,9 & 80,4 & 90,5 \\
\hline $75-79$ & 70,7 & 83,6 & 91,2 & 65,3 & 85,2 & 91,8 \\
\hline $80-84$ & 69,7 & 83,6 & 91,2 & 67,1 & 86,8 & 91,6 \\
\hline $85-89$ & 68,9 & 87,6 & 89,8 & 65,0 & 83,9 & 90,6 \\
\hline $90+$ & 62,3 & 81,3 & 88,5 & 64,8 & 76,1 & 81,3 \\
\hline $70+$ & 69,2 & 84,0 & 90,5 & 64,5 & 83,0 & 91,0 \\
\hline $\begin{array}{l}\text { Poliklinikk } \\
70-74\end{array}$ & 12,2 & 44,1 & 35,8 & 13,7 & 45,2 & 38,2 \\
\hline $75-79$ & 13,2 & 48,6 & 35,4 & 13,1 & 49,7 & 38,0 \\
\hline $80-84$ & 10,6 & 49,7 & 34,3 & 12,9 & 48,3 & 36,3 \\
\hline $85-89$ & 8,0 & 45,9 & 31,1 & 12,3 & 48,0 & 25,3 \\
\hline $90+$ & 9,9 & 35,3 & 28,0 & 10,4 & 37,8 & 20,0 \\
\hline $70+$ & 11,8 & 46,5 & 34,8 & 13,2 & 47,1 & 36,8 \\
\hline
\end{tabular}

Det var en stor økning i bruken av lege i sykehus (poliklinikk) fra HUNT1 til HUNT2, med en tydelig reduksjon fra HUNT2 til HUNT3.

\section{SYKDOMMER}

I HUNT1 rapporterte 68\% at de hadde langvarig sykdom (>1 år), skade eller lidelse av en slik art at det hemmet dem i dagliglivet. Andelen $\emptyset$ kte med alderen - til over 8o\% hos dem som var 90 år og eldre. Andelen var vesentlig lavere i HUNT2 og i HUNT3.

Selvrapportert koronarsykdom viste en topp ved HUNT2, dette gjaldt for de fleste aldersgrupper og begge kjønn (fig 4). Det var en økning i hjerneslag hos menn fra HUNT1 til HUNT3 i de fleste aldersgruppene, mens det hos kvinner var mindre endringer. 


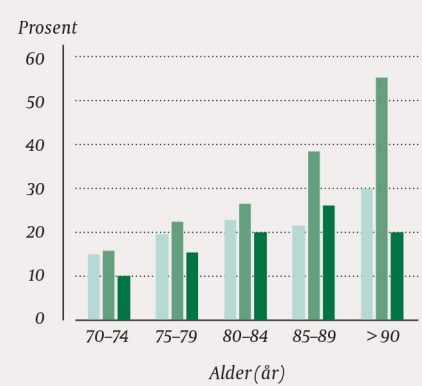

Koronarsykdom

a) Kvinner

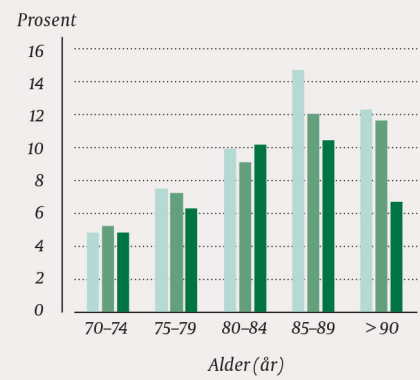

Hjerneslag

a) Kvinner

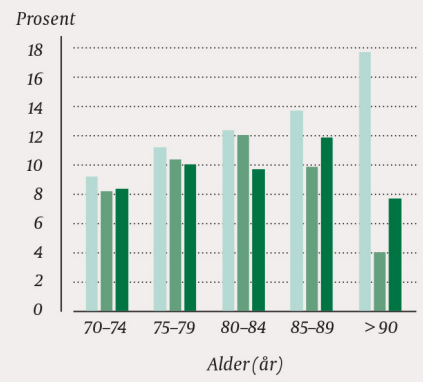

Diabetes

a) Kvinner

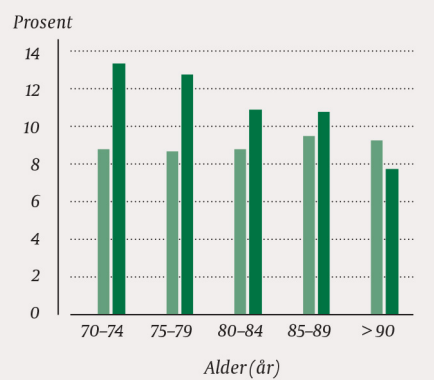

Astma

a) Kvinner

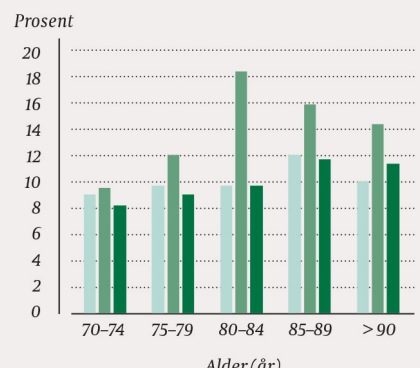

Psykiske plager

a) Kvinner

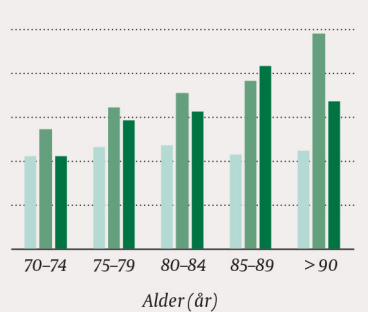

b) Menn

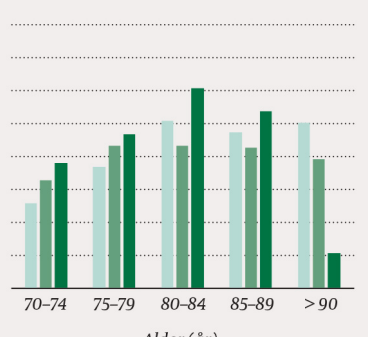

Alder (år)

b) Menn

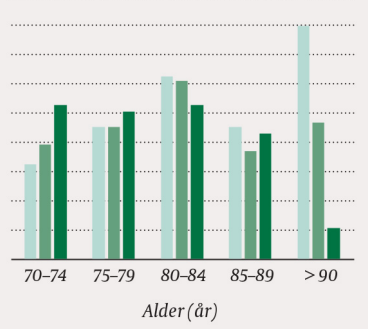

b)Menn

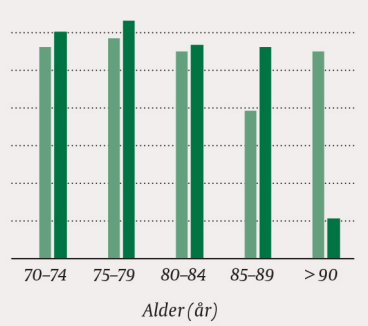

b) Menn

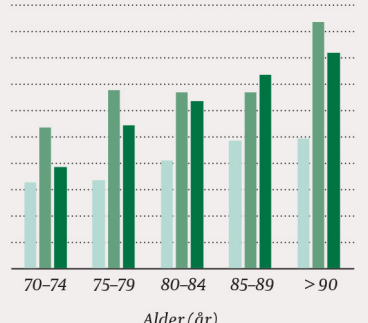

b) Menn 
Figur 4 Selvrapportert sykdom hos deltagere som var 70 år og eldre ved HUNT1, HUNT2 og HUNT3 hos a) kvinner og b) menn. Aldersfordelt

Forekomsten av diabetes gikk ned hos kvinnene og økte hos mennene, men disse endringene var ikke statistisk signifikante (fig 4). Selvrapporterte psykiske plager viste en topp ved HUNT2, mest uttalt hos kvinner (9,6\%, 12,5\%, 9,1\% hos kvinner og 7,2\%, 12,2\% og 10,2\% hos menn ved HUNT1, HUNT2 og HUNT3).

\section{Diskusjon}

Denne studien, som viser data fra tre tverrsnitt fra HUNT-unders $\emptyset$ kelsene i 2o-årsperioden fra 1984-86 til 2006-o8, tyder på at det har vært en positiv utvikling i de eldres funksjonsnivå og subjektive helse. Det gjelder begge kjønn og i alle aldersgrupper. Forekomsten av selvrapporterte sykdommer varierte gjennom perioden, uten noen klare tendenser. Det var redusert bruk av hjemmehjelp, men sterk økning i bruken av allmennlege i perioden.

En styrke ved denne studien er det store antallet deltagere, noe som gjør det mulig å stratifisere på kjønn og femårs aldersgrupper. På grunn av synkende deltagelse i de øverste aldersgruppene må man likevel ta forbehold, særlig når det gjelder de aller eldste. Dansk forskning på disse viser imidlertid samme utvikling som vårt materiale antyder (18). Målingene er gjennomført etter samme mønster ved alle de tre undersøkelsene. HUNT-data er dessuten relevante for resten av Norge, ettersom Nord-Trøndelag i noen grad er representativ for landet vårt, selv om det ikke er noen storby i fylket (21).

De som deltok i HUNT-undersøkelsene, måtte være så friske at de kunne fylle ut spørreskjema og møte frem ved en feltstasjon for klinisk undersøkelse. De aller sykeste i fylket deltok defor i lite omfang, dette gjelder alle de tre undersøkelsene. Synkende deltagelse er imidlertid en utfordring, ettersom det tidligere er vist at de som ikke møtte ved $\mathrm{HUNT}_{3}$, hadde en noe mer ugunstig livsstil og generelt noe dårligere helse enn de som møtte (26). Noe av den registrerte bedringen i helsetilstand som våre data viser kan dermed skyldes økende seleksjon.

Det er imidlertid vist at også blant de eldre deltagerne var det en betydelig økning i forekomsten av overvekt og fedme (27). Videre er det vist at antallet som aldri har tatt blodtrykksmedisin er redusert, og at blodtrykket er gått ned hos både disse og hos dem som tar medisiner (28).

Den økte fysiske aktiviteten som er registrert, stemmer overens med resultater fra studier i Sverige, der det er funnet økt aktivitet i alle aldersgrupper. Våre data er basert på selvrapportering, og det er grunn til å anta at særlig for livsstilsfaktorer rapporterer folk sine egne vaner som gunstigere enn de faktisk er. Siden vi har analysert to tverrsnitt av samme befolkning (HUNT1 og HUNT3), kan man likevel legge vekt på endringene over tid. Evalueringsstudier har imidlertid vist at HUNT-spørsmålene særlig fanger opp hard fysisk aktivitet, mens den lettere aktiviteten ikke blir like pålitelig registrert (25).

Ett hovedfunn er bedring i ADL-funksjonene. Deltagerne ved HUNT3 rapporterte om stor grad av selvhjulpenhet, og sammenlignet med tall fra Sverige (10) hadde HUNT-deltagerne bedre ADL-funksjoner. I studier av de aller eldste i Danmark var det en klar positiv utvikling (29), og i flere andre undersøkelser fra før år 2000 har man funnet det samme $(13,15)$. I en britisk undersøkelse er det vist bedring i funksjoner fra 1998 til 2008 (15).

I vårt materiale fant vi ingen klare tendenser i utviklingen av selvrapportert sykdom. For begge kjønn ble det rapportert mer koronarsykdom i HUNT2 enn i både HUNT1 og HUNT3. I en nederlandsk studie fant man mindre hjertesykdom, astma og hjerneslag, men økt prevalens av diabetes i perioden 1987-2001 (30), og Wolf og medarbeidere fant at sykdom inntraff noe senere hos eldre i perioden 1982-94 (31).

Det var en markant nedgang i bruk av hjemmehjelp fra HUNT2 til HUNT3, noe som er i 
samsvar med andre funn i Norge (32). Dette har trolig sammenheng med at hjemmesykepleien var gratis for innbyggerne i 1998, mens det i 1990-årene ble gradvis økt egenandel på hjemmehjelp (33). Den økte bruken av allmennlege samsvarer med tall fra Statistisk sentralbyrå (34). Den økte bruken av polikliniske spesialisthelsetjenester som fant sted i perioden mellom HUNT2 og HUNT3 samsvarer med det som Sintef har vist (35).

Målet med denne studien var å undersøke om eldre hadde fått bedre helse og ADL-funksjon i løpet av 20-årsperioden fra HUNT1 (1984-86) til HUNT3 (2006-08). Til tross for noen svakheter i materialet tyder data på at de eldre nordtrønderne hadde både bedre helse og bedre ADL-funksjoner ved HUNT3 enn tidligere.

Dersom eldre synes de har god funksjonsevne og brukbar helse selv om de kan ha flere diagnoser, kan dette være en viktig modererende faktor når eldrebølgen kommer.

Våre data er snart ti år gamle, og sosial gradienter i utviklingen er ikke undersøkt. Nyere amerikanske studier tyder på at helseutviklingen ikke endres for lavere sosiale grupper, men bedres for de bedrestilte (36),og Krokstad og medarbeidere har vist at helseutsiktene har en klar sosial gradient (37).

\section{Konklusjon}

Vårt materiale indikerer at nordtrøndere som var 70 år og eldre hadde bedre ADL-funksjon og bedre subjektiv helse ved HUNT3 (2005-07) enn ved HUNT2 (1995-97) og HUNT1

(1984-86), mens forekomsten av ulike sykdommer ikke viste noen entydig tendens. Bruken av hjemmehjelp avtok i perioden, bruken av allmennlege $\varnothing \mathrm{kte}$.

Funnene må tolkes med forsiktighet på grunn av sannsynlig seleksjon som følge av fallende deltagelse fra HUNT1 til HUNT3.

\section{HOVEDBUDSKAP}

Deltagerne I HUNT3 (2006-08) som var 70 år og eldre hadde bedre ADL-funksjoner enn deltagerne i HUNT1 (1984-86) og HUNT2 (1995-97)

De var mer fysisk aktive

De hadde bedre subjektiv helse

De brukte hjemmehjelp sjeldnere, men allmennlegen oftere

Studiedeltagelsen sank fra 83,4\% i HUNT1 til 54,6\% i HUNT 3

\section{LITTERATUR:}

1. Syse A, Dinh QP. Befolkningsframskrivninger 2014-210o. Dødelighet og levealder. https://www.ssb.no/befolkning/artikler-og-publikasjoner/_attachment/194976?_ts=1483a29e810 (22.5.2017).

2. Jacob ME, Yee LM, Diehr PH et al. Can a Healthy Lifestyle Compress the Disabled Period in Older Adults? J Am Geriatr Soc 2016; 64: 1952 - 61. [PubMed][CrossRef]

3. Sierra F, Hadley E, Suzman R et al. Prospects for life span extension. Annu Rev Med 2009; 6o: 457 - 69. [PubMed][CrossRef]

4. Parker MG, Schön P, Lagergren M et al. Functional ability in the elderly Swedish population from 1980 to 2005. Eur J Ageing 2008; 5: 299-309. [CrossRef]

5. Manton KG. Changing concepts of morbidity and mortality in the elderly population. Milbank Mem Fund Q Health Soc 1982; 60: 183 - 244. [PubMed][CrossRef]

6. Langballe EM, Strand BH. Vil fremtidens eldre være friskere? Tidsskr Nor Legeforen 2015; 135: 113 - 4 . [PubMed][CrossRef] 
7. Chatterji S, Byles J, Cutler D et al. Health, functioning, and disability in older adults-present status and future implications. Lancet 2015;385:563-75. [PubMed][CrossRef]

8. Galenkamp H, Braam AW, Huisman M et al. Seventeen-year time trend in poor self-rated health in older adults: changing contributions of chronic diseases and disability. Eur J Public Health 2013; 23: 511 - 7. [PubMed][CrossRef]

9. Hjort PF. Helsebegrepet, helseidealet og helsepolitiske mål. I: Helsepolitikk og helseadministrasjon. Oslo: Tanum-Nordli, 1982:11-31.

10. Lennartsson C, Heimerson I. Elderly people's health: Health in Sweden: The National Public Health Report 2012. Chapter 5. Scand J Public Health 2012; 40: 95-120. [PubMed][CrossRef]

11. Fors S, Lennartsson C, Agahi N et al. Intervjustudie om de allra äldstas levnadsvillkor. Äldre har fått fler hälsoproblem, men klarar vardagen bättre. Lakartidningen 2013; 110: 1403 - 5. [PubMed]

12. Modig K, Virtanen S, Ahlbom A et al. Stable or improved health status in the population 65 years and older in Stockholm, Sweden - an 8-year follow-up of self-reported health items. Scand J Public Health 2016; 44: 480 - 9. [PubMed][CrossRef]

13. Spillman BC. Changes in elderly disability rates and the implications for health care utilization and cost. Milbank Q 2004; 82: 157 - 94. [PubMed][CrossRef]

14. Murabito JM, Pencina MJ, Zhu L et al. Temporal trends in self-reported functional limitations and physical disability among the community-dwelling elderly population: the Framingham heart study. Am J Public Health 2008; 98: 1256 - 62. [PubMed][CrossRef]

15. Donald IP, Foy C, Jagger C. Trends in disability prevalence over 10 years in older people living in Gloucestershire. Age Ageing 2010;39:337 - 42. [PubMed][CrossRef]

16. Sagardui-Villamor J, Guallar-Castillón P, García-Ferruelo M et al. Trends in disability and disabilityfree life expectancy among elderly people in Spain:1986-1999. J Gerontol A Biol Sci Med Sci 2005; 60: 1028 -34. [PubMed][CrossRef]

17. Zunzunegui MV, Nunez O, Durban M et al. Decreasing prevalence of disability in activities of daily living, functional limitations and poor self-rated health: a 6-year follow-up study in Spain. Aging Clin Exp Res 2006; 18:352 - 8. [PubMed][CrossRef]

18. Christensen K, McGue M, Petersen I et al. Exceptional longevity does not result in excessive levels of disability. Proc Natl Acad Sci U S A 2008; 105: 13274 - 9. [PubMed][CrossRef]

19. Nybo H, Gaist D, Jeune B et al. Functional status and self-rated health in 2,262 nonagenarians: the Danish 1905 Cohort Survey. J Am Geriatr Soc 2001; 49: 6o1 - 9. [PubMed][CrossRef]

20. Holmen J, Midthjell K, Forsén L et al. Helseundersøkelsen i Nord-Trøndelag 1984-86. Fremmøtet og sammenlikning av dem som møtte og dem som ikke møtte. Tidsskr Nor Lægeforen 1990; 110: 1973 - 7. [PubMed]

21. Krokstad S, Langhammer A, Hveem K et al. Cohort Profile: the HUNT Study, Norway. Int J Epidemiol 2013; 42: 968 - 77. [PubMed][CrossRef]

22. Holmen J, Midthjell K, Krüger $\emptyset$ et al. The Nord-Trøndelag Health Study 1995-97 (HUNT2):

Objectives, contents, methods and participation. Nor Epidemiol 2003; 13:19-32.

23. Lawton MP. The functional assessment of elderly people. J Am Geriatr Soc 1971; 19:465 - 81. [PubMed][CrossRef]

24. Kurtze N, Gundersen KT, Holmen J. Selvrapportert fysisk aktivitet i norske befolkningsundersøkelser - et metodeproblem. Nor Epidemiol 2003; 13: 163 - 70.

25. Kurtze N, Rangul V, Hustvedt BE et al. Reliability and validity of self-reported physical activity in the Nord-Trøndelag Health Study: HUNT 1. Scand J Public Health 2008; 36: 52 - 61. [PubMed]

26. Langhammer A, Krokstad S, Romundstad P et al. The HUNT study: participation is associated with survival and depends on socioeconomic status, diseases and symptoms. BMC Med Res Methodol 2012; 12:143. [PubMed][CrossRef]

27. Midthjell K, Lee CM, Langhammer A et al. Trends in overweight and obesity over 22 years in a large adult population: the HUNT Study, Norway. Clin Obes 2013; 3: 12 - 20. [PubMed][CrossRef]

28. Holmen J, Holmen TL, Tverdal A et al. Blood pressure changes during 22-year of follow-up in large 
general population - the HUNT Study, Norway. BMC Cardiovasc Disord 2016; 16: 94.

[PubMed][CrossRef]

29. Christensen K, Thinggaard M, Oksuzyan A et al. Physical and cognitive functioning of people older than go years: a comparison of two Danish cohorts born 10 years apart. Lancet 2013; 382:1507-13.

[PubMed][CrossRef]

30. Puts MT, Deeg DJ, Hoeymans N et al. Changes in the prevalence of chronic disease and the

association with disability in the older Dutch population between 1987 and 2001. Age Ageing 2008; 37 : 187 - 93. [PubMed][CrossRef]

31. Wolf DA, Mendes de Leon CF, Glass TA. Trends in rates of onset of and recovery from disability at older ages: 1982-1994. J Gerontol B Psychol Sci Soc Sci 2007; 62: S3 - 10. [PubMed][CrossRef]

32. Otnes B. Seniorer i Norge. Hjelpebehov og tjenestetilbud. Kap. 8. Oslo: Statistisk sentralbyrå, 2010: 127-41.

33. Abrahamsen DR, Svalund J. Flere eldre mottar hjemmesykepleie. Samfunnsspeilet 2005; nr. 4. https://www.ssb.no/helse/artikler-og-publikasjoner/flere-eldre-mottar-hjemmesykepleie (22.5.2017).

34. McMurray A, Chaboyer W, Wallis M et al. Patients' perspectives of bedside nursing handover. Collegian 2011; 18:19 - 26. [PubMed][CrossRef]

35. Pettersen IJ, Jørgenvåg R, Nyland K. Sentrale utviklingstrekk innen spesialisthelsetjenesten 1999-2003. Trondheim: SINTEF Helse, 2003.

36. Tsai Y. Education and disability trends of older Americans, 2000-2014. J Public Health (Oxf) 2016. [PubMed][CrossRef]

37. Krokstad S, Ernstsen L, Sund ER et al. Social and spatial patterns of obesity diffusion over three decades in a Norwegian county population: the HUNT Study. BMC Public Health 2013; 13: 973. [PubMed][CrossRef]

Publisert: 18. september 2017. Tidsskr Nor Legeforen. DOI:10.4045/tidsskr.16.0557

Mottatt 21.6.2016, første revisjon innsendt 2.12.2016, godkjent 22.5.2017.

(C) Tidsskrift for Den norske legeforening 2020. Lastet ned fra tidsskriftet.no 